\title{
Revisitando os caminhos de Marie Curie no interior de Minas Gerais
}

\author{
Ana Luiza Santos Fagundes Costa (UFJF) \\ Stephany Prado Spatz (UFJF)
}

RESUMO-PÔSTER

Na década de 20, Marie Curie (1867-1934) vivenciava o auge da sua carreira como cientista, bastante conhecida em todo o mundo e detentora de dois prêmios Nobel em Ciências, a cientista teve excelente receptividade ao visitar o Brasil em 1926, que nesse período possuía um grande interesse pela ciência, sendo então convidada pelo Instituto Franco Brasileiro de Alta Cultura para ser a principal oradora de uma série de conferências sobre radioatividade na Escola Politécnica da Universidade Federal do Rio de Janeiro, quando suas palestras obtiveram grande destaque na época. A comitiva de cientistas da qual Marie Curie fazia parte chegou a Belo Horizonte em 26 de agosto de 1926 para conhecer o Instituto do Rádio que fora construído em 1922 com a finalidade de se estudar o elemento rádio e os Raios- $X$. $O$ instituto foi de grande importância na pesquisa e desenvolvimento dos conhecimentos da área de radiologia, contribuindo dessa forma, para a medicina brasileira. 0 presente trabalho aborda, através de pesquisas e levantamentos de arquivos históricos, a trajetória de Marie Curie em terras brasileiras, especialmente em sua rota no interior de Minas Gerais, visto que quase não existem divulgações sobre seu percurso e sobre os objetivos dessas viagens. 